\title{
Secondary traumatic stress in Turkish aid workers: Adaptation of a measure and investigation of secondary traumatic stress
}

\author{
Ayla Kahil ${ }^{1}$, Refia Palabıyıkoğlu ${ }^{2}$
}

\author{
Key words \\ secondary traumatic \\ stress, vicarious \\ traumatization, aid \\ workers, secondary \\ traumatic stress scale
}

\section{Anahtar kelimeler}

ikincil travmatik stress, dolaylı travmatizasyon, yardım çalışanları, ikincil travmatik stress ölçeği

\begin{abstract}
This study aims to investigate the secondary traumatic stress symptoms of aid workers who care for trauma victims as part of their jobs or as volunteers. To this end, Secondary Traumatic Stress Scale was adapted to Turkish and implemented to 228 professional and voluntary aid workers. Data were analyzed with respect to participants' type of work (being either a professional or a volunteer aid worker), sex, age, education level, years spent at recruitment, presence of a traumatic incident, and type of traumatic incident. Analyses revealed that professional aid workers experienced more traumatic stress symptoms compared to volunteer aid workers. Furthermore, it was found that participants who had been working for between 11 and 15 years experienced more traumatic stress symptoms than those who had been working for between 1 and 5 years. These findings indicate that aid workers who had experienced an incident that they consider as traumatic showed more secondary traumatic stress symptoms as opposed to those who had not experienced a traumatic incident. Notably, no significant difference was found between participants who were exposed to the traumatic incident indirectly due to their work and participants who experienced the traumatic incident in their personal lives. This finding points out that exposure to a secondary traumatic incident leads to similar responses and experiences with direct exposure.
\end{abstract}

\section{$\ddot{O} z$}

Türk yardım çalışanlarında ikincil travmatik stres: Ölçek uyarlaması ve ikincil travmatik stresin incelenmesi

$\mathrm{Bu}$ araştırmada, travmatik yaşantıları olan bireylere, travma anında veya sonrasında müdahalede bulunan profesyonel ve gönüllü yardım çalışanlarının, yaptıkları yardım davranışı sonucunda deneyimledikleri ikincil travmatik stres belirtilerinin incelenmesi hedeflenmiştir. Bu amaç doğrultusunda, İkincil Travmatik Stres Ölçeği Türkçeye uyarlanmış ve 228 profesyonel ve gönüllü yardım çalışanına uygulanmıştır. Travmatik stres belirtileri mesleki işlev (profesyonel yardım çalışanı veya gönüllü yardım çalışanı olmak), cinsiyet, yaş, eğitim düzeyi, mesleki deneyim süresi, travmatik yaşam olayı varlığı ve travmatik yaşantının türü değişkenlerine göre incelenmiştir. Yapılan analizler sonucunda, profesyonel yardım çalışanlarının, gönüllü yardım çalışanlarına göre daha fazla travmatik stres belirtileri deneyimledikleri saptanmıştır. Yanı sıra, mesleğinde 11-15 yıldır çalışmakta olan katılımcıların travmatik stres belirtilerinin, mesleğini 1-5 yıldır sürdürmekte olan katılımcıların stres belirtilerinden daha yüksek olduğu bulunmuştur. Travmatik olarak değerlendirdikleri yaşam olayları deneyimleyen yardım çalışanlarının ikincil travmatik stres belirtilerinin, travmatik bir yaşam olayı deneyimlemeyen katılımcıların belirtilerinden daha yüksek olduğu sonucuna varılmıştır. Dikkat çekici olarak, yaşadıkları travmatik olaya meslekleri sebebi ile maruz kalan katılımcılar ile, yıkıcı yaşantısı kişisel hayatlarında meydana gelmiş olan katılımcıların, ikincil travma belirtileri arasında bir farklılık olmadığı görülmüştür. Bu sonuç, ikincil olarak travmatik bir olaya maruz kalmanın, doğrudan maruziyet ile benzer tepkiler ve yaşantılar ortaya çıkardığına işaret etmektedir.

Kahil, A., \& Palabıyıkoğlu, R. (2018). Secondary traumatic stress in Turkish aid workers: Adaptation of a measure and investigation of secondary traumatic stress. Klinik Psikoloji Dergisi, 2(3), 107-116.

\footnotetext{
$\triangle$ Ayla Kahil·aylakahil@hotmail.com

${ }^{1}$ Uzm. Psk., Girne Mah. 100. Y11, 9/2 Çankaya/Ankara.

${ }^{2}$ Prof. Dr., Ufuk Üniversitesi, Psikoloji Bölümü, İncek/Ankara, 06836.

Note: This article is based on the first author's master's thesis which was conducted under supervision of the second author.
}

Received 16 April 2018

Accepted 6 September 2018 
Traumatic events do not affect only the victims who were under direct exposure, but these incidents might as well lead to some drastic symptoms on the people whom victims receive help during or after traumatic incidents. A person who is exposed to a traumatic event encounters or witnesses an actual life threat and/or severe physical injury risk to which he responds with intense fear, horror or helplessness (APA, 2000). During these incidents or in the aftermath, some survivors might need help since their physical and/or psychological health is impaired. The nature of this helping relationship carries a "contagion" risk for aid workers through the instrumentality of the intervention and assistance they provide to the survivors. Aid workers as well, might experience traumatic stress symptoms as their clients do. Since the exposure in question has an indirect aspect, literature suggests the use of "secondary traumatic stress" (STS) term to refer to traumatic experiences of people who work with traumatized clients (Bride, 2007; Dirkzwager, Bramsen, Adér, \& van der Ploeg, 2005; Figley, 1998; Figley \& Kleber, 1995; Saakvitne, 2002).

As stated before, studies conducted with professionals who engage in help behaviors indicate that many workers show secondary traumatic stress symptoms similar to post-traumatic stress disorder (PTSD) symptoms-like (Bonach \& Heckert, 2012; Bride, 2007; Bride, Jones, \& Macmaster, 2008; Smith Hatcher, Bride, Oh, King, \& Catrett, 2011; Y1lmaz \& Şahin, 2007). The basic difference is that the source of the problem, which is trauma in this context, belongs to another person (Figley, 1995). Research has revealed an association between secondary traumatic stress level and numerous variables such as sex (e.g., Haksal, 2007), clinical supervision attendance (e.g. Ewer, Teesson, Sannibale, Roche, \& Mills, 2014), work load (e.g. Altekin, 2014), professional experience (e.g. Schwartz, 2008), perceived social support (e.g. Perez, Jones, Englert, \& Sachau, 2010), burnout (e.g. Adams, Boscarino, \& Figley, 2006; Gürdil Birinci, \& Erden, 2016), and coping strategies (e.g. Littleton, Horsley, John, \& Nelson, 2007). Participants of STS studies mostly consist of health workers, namely, nurses and doctors (Beck, 2011; Dominguez-Gomez \& Rutledge, 2009; Duffy, Avalos, \& Dowling, 2015; Haksal, 2007; Healy \& Tyrrell, 2011; Robins, Meltzer, \& Zelikovsky, 2009; Yeşil, 2010), mental health professionals including therapists, psychologists, social workers, psychiatrists, and psychological counselors (Altekin, 2014; Creamer \& Liddle, 2005; Devilly, Wright, \& Valker, 2009; Ortlepp \& Friedman, 2005), fire fighters (Beaton, Murphy, Johnson, \& Nemuth, 2004; Wagner, Heinrichs, \& Ehlert), and child welfare workers (Bonach \& Heckert, 2012; Bride et al., 2008; Çolak, Şişmanlar, Karakaya, Etiler, \& Biçer, 2012; Smith
Hatcher et al., 2011). The fact that STS studies have been conducted mostly with the aforementioned participant groups does not suggest that only these professions are at risk for STS. Considering an ambulance asked for a car crash, not only the doctor and emergency medical technician in the vehicle are exposed to emergency scene, but also the driver faces the same exposure. From this perspective, STS research with disregarded or less studied populations seems to be important.

In the light of the literature mentioned above, it is important that psychological experiences of vicariously traumatized populations are investigated. Within the scope of the existing literature, any research comparing STS symptoms in professional and volunteer aid workers was lacking in both international and Turkish literature. The current study aimed to close this gap in the literature. In addition, literature review conducted on the topic revealed the fact that academic publications on STS conducted with Turkish samples employed instruments, which were originally developed with the purpose of measuring primary traumatic stress and PTSD. Thus, another aim of the current study was to adapt Secondary Traumatic Stress Scale (STSS) developed by Bride, Robinson, Yegidis, and Figley (2004) to Turkish. Research using STSS suggests that the scale was commonly and successfully employed to measure STS in people who work with traumatized populations (Bonach \& Heckert, 2012; Bride, 2007; Bride et al., 2008; Bride, Smith Hatcher, \& Humble, 2009; Choi, 2011; Dirkzwager et al., 2005; Ewer et al., 2014; Perez et al., 2010; Smith Hatcher et al., 2011; Ting, Jacobson, Sanders, Bride, \& Harrington, 2005). By adapting the instrument, it was aimed to standardize STS measurement within the Turkish literature. Such standardization effort will enable future research to make more precise and consistent comparisons between different studies. This study is based on the first author's research conducted as part of her master's thesis study under supervision of the second author. At the time this study was conducted, STSS was not adapted to Turkish. However, during the preparation of this manuscript an article on STSS adaptation was published (Yıldırım, Kıdak, \& Yurdabakan, 2018). A brief comparison of features of the two versions of STSS can be found in the Method section. Based on the above-mentioned rationale for conducting the present study, the primary aim was to adapt STSS to the Turkish culture and investigate the difference of the intensity of STS levels between professional and volunteer aid workers working with traumatized clients. The secondary aim was to compare the intensity of aid workers' STS levels in terms of their sex, age, education level, years spent at recruitment, presence of a traumatic incident, and type of traumatic incident. 


\section{METHOD}

In this quantitatively descriptive study, the term professional was operationally defined as working on a monthly salary in a governmental institution for the relief of people who have experienced traumatic events. On the other hand, the term volunteer was operationally defined as voluntarily serving as a relief worker and not being paid for the service provided. Still, it should be noted that most of the participants in the volunteer category were vocational professionals, but they were categorized in the volunteer group because they engaged in unpaid help behavior.

\section{Sample and Procedure}

The sample of the study consisted of 106 women and 120 men, corresponding to a total of 228 aid workers (missing value $=2 ; 0.9 \%) .202(88.6 \%)$ participants were professional aid workers and the remaining 26 (11.4\%) were volunteers. Professions of professional aid worker participants included emergency medical technicians, doctors, nurses, mental health professionals, managers, sociologists, army officers, rescue workers, and humanitarian aid workers, among many others. Professions of volunteer aid worker participants included engineers, social workers, sociologists, psychologists, government officers, finance officers, and teachers. The participants were from four organizations and three different professional associations. Detailed demographic information of the participants can be seen in Table 1 .

After receiving the approval of Ufuk University Ethics Committee for conducting the study, several governmental and nongovernmental aid organizations were contacted and necessary institutional permissions (written or oral) were obtained. The data were gathered during April-September 2015. A total of 327 surveys were conducted. However, 99 (30.27\%) of the surveys were excluded because of either high rate of missing data or the particular respondent's job did not require working with traumatized people. As a result, surveys of 228 participants were included in the study, with a response rate of $69.73 \%$.

\section{Measures}

Demographic Information Questionnaire (DIQ) Information on the demographic characteristics of the participants was obtained by the DIQ developed specifically for this study. This form included questions regarding the independent variables of the study along with questions such as occupation, marital status, and presence of children. Participants were also asked to indicate whether or not their work required exposure to their clients' traumatic events and, if yes, to briefly explain the event which influenced
Table 1. Frequencies and Percentages of the Demographic Characteristics of the Participants

\begin{tabular}{|c|c|c|}
\hline Variable & $n *$ & $\%$ \\
\hline \multicolumn{3}{|l|}{ Type of work behavior } \\
\hline Professional & 202 & 88.6 \\
\hline Volunteer & 26 & 11.4 \\
\hline \multicolumn{3}{|l|}{ Sex } \\
\hline Female & 106 & 46.5 \\
\hline Male & 120 & 52.6 \\
\hline Missing value & 2 & .9 \\
\hline \multicolumn{3}{|l|}{ Age group } \\
\hline $18-24$ & 15 & 6.6 \\
\hline $25-30$ & 67 & 29.4 \\
\hline $31-40$ & 107 & 46.9 \\
\hline $41-50$ & 32 & 14.0 \\
\hline $51+$ & 6 & 2.6 \\
\hline Missing value & 1 & .4 \\
\hline \multicolumn{3}{|l|}{ Education status } \\
\hline High school & 11 & 4.8 \\
\hline Higher education & 150 & 65.8 \\
\hline Master's & 54 & 23.7 \\
\hline $\mathrm{PhD}$ & 13 & 5.7 \\
\hline \multicolumn{3}{|l|}{ Years spent at recruitment } \\
\hline $1-5$ & 82 & 36.0 \\
\hline $6-10$ & 59 & 25.9 \\
\hline $11-15$ & 46 & 20.2 \\
\hline $16-20$ & 17 & 7.5 \\
\hline $21-25$ & 12 & 5.3 \\
\hline $26+$ & 9 & 3.9 \\
\hline Missing value & 3 & 1.3 \\
\hline \multicolumn{3}{|c|}{ Presence of personal traumatic incident } \\
\hline No & 109 & 47.8 \\
\hline Yes & 105 & 46.1 \\
\hline Missing value & 14 & 6.1 \\
\hline \multicolumn{3}{|c|}{ Theme of the traumatic incident } \\
\hline None & 109 & 47.8 \\
\hline Work related & 24 & 10.5 \\
\hline Personal & 62 & 27.2 \\
\hline Missing value & 35 & 15.4 \\
\hline
\end{tabular}

them the most ("Regarding your work or volunteerism, did your course of action demand you to listen to traumatic experiences of the people with whom you are in a professional relationship?). This particular question was considered to be the exclusion criteria for the study; data of the participants who answered no to this question were excluded. In addition, the DIQ involved a question about the respondent's perceived personal traumatic incident ("Did you experience a life event which you consider to be a traumatic incident?). Following this item, participants were asked to briefly explain that traumatic incident which then was categorized by the researchers as being either a personal life related traumatic event or a work life related traumatic event. Participants were asked to report only one incident; however, some reported two different incidents. For those cases, the first reported incident was used. That is, the event, 
which was written first by the respondent was categorized according to its type (i.e., work life related traumatic incident vs. personal life related traumatic incident) and accordingly used for further analysis. Incidents listed under the work life related traumatic events included incidents such as rescuing a person from a building wreck following an earthquake, providing first aid intervention to a person who has just been in a car crash, collecting body remains of a deceased, and rescuing a child from an abusive parent. All these mentioned events address clients' traumatic incidents that the respondents were exposed to vicariously. On the other hand, incidents such as loss of a spouse, surviving a car accident, life threatening health issues (such as cancer), torture, rape, and physical assault were classified as personal life related traumatic events.

Secondary traumatic stress scale (STSS) STSS (Bride et al., 2004) is a 17-item, 5-point Likert selfreport measure which was developed to assess the STS symptoms in trauma related profession populations. Each of the 17 items in the scale addresses the corresponding symptom of the B (intrusion), C (avoidance), and D (hypervigilance) diagnostic criteria for PTSD as defined in DSM-IV-TR (APA, 2000). The possible range of the measure is between 17 and 85, with higher scores indicating higher levels of stress. The scale is a multidimensional measure consisting of three different subscales named as Intrusion, Avoidance, and Arousal. Overall Cronbach's alpha coefficient for all the 17 items of the scale is .94; whereas for the Intrusion, Avoidance, and Arousal subscales the coefficients were $.83, .89$, and .85 , respectively.

STSS was adapted to Turkish by Kahil (2016) as part of a master's thesis study conducted under the supervision of the second author. Following the grant of permission for the scale adaptation process, the items were translated to Turkish and revised by a Psychology professor, a Psychological Counseling and Guidance professor, and an English language specialist who were fluent in both English and Turkish. Then, the items were back translated to English by an assistant professor of Psychological Counseling and Guidance major and a comparison was made between the back-translated form and the original English form. After the necessary corrections were made, the final version was decided to be adequate to be used in the study. An exploratory factor analysis was performed using Principal Components Analysis with varimax rotation. The analyses revealed a twofactor solution; however, the distribution of the items under two factors failed to indicate a meaningful reasoning. It is known that, for a measure to be considered as a unidimensional construct, the first dimension of the scale should explain more than $30 \%$ of the variance. Moreover, the eigenvalue of the first dimension should be at least three times greater than the eigenvalue of the second dimension. Meeting these criteria, the Turkish version of the STSS was decided to reflect a unidimensional structure. Confirmatory factor analyses also supported this unidimensional construct. It should be noted that another study examining the psychometric properties of the STSS also found unidimensionality (Ting et al., 2005). The internal consistency reliability of the adapted STSS was found to be very high with a Cronbach alpha coefficient of .94. The split-half reliability analysis showed a high correlation between the two halves of the measure with a correlation coefficient of .83 and with a Guttman Split-Half coefficient of .90 .

Other than Kahil's (2016) STSS adaptation, the scale was adapted into Turkish by Yildırım et al. (2018). That adaptation version resulted in a threedimensional construct as the original STSS form. Cronbach's alpha coefficient for all the scale items was calculated as .91; whereas for the Intrusion, Avoidance, and Arousal subscales the coefficients were found to be $.84, .78$, and .82 , respectively. Comparing Kahil's (2016) and Ylldirım et al.'s (2018) adaptation studies, it is possible to say that there are differences between the translations of instrument items into Turkish.

\section{Analysis of Data}

Before proceeding to the statistical analysis stage of the study, data were examined in terms of outliers, missing values, and homogeneity of variances. Statistical analyses conducted were decided on in accordance with the homogeneity of variances results as either parametric or nonparametric analysis.

\section{RESULTS}

\section{Frequency of Symptoms}

According to Bride et al. (2004), to be able to discuss the existence of a symptom, the relevant item should be indicated by the respondent as "occasionally", "often" or "very often". The most frequent symptoms, which were experienced by all participants (including both professional and volunteer aid workers), were emotional numbing (53.9\%), experiencing psychological distress in response to the reminders of work with clients (47.8\%), and difficulty in sleeping $(38.1 \%)$. On the contrary, the least experienced symptoms were disturbing dreams regarding clients $(14.5 \%)$, inability to recall information about clients (19.7\%), and hypervigilance (29\%).

Both similarities and differences were noted when the frequency of symptoms reported by the two 
Table 2. Frequency of STSS Items Reported by Professional and Volunteer Aid Workers

\begin{tabular}{|c|c|c|c|c|c|c|c|}
\hline (Item number) Item & $\begin{array}{l}\text { Never } \\
n(\%)\end{array}$ & $\begin{array}{c}\text { Rarely } \\
n(\%)\end{array}$ & $\begin{array}{c}\text { Occasionally } \\
n(\%)\end{array}$ & $\begin{array}{l}\text { Often } \\
n(\%)\end{array}$ & $\begin{array}{c}\text { Very Often } \\
n(\%)\end{array}$ & $M$ & $S D$ \\
\hline \multicolumn{8}{|l|}{ (1) Emotional numbing } \\
\hline Professional aid workers* & $\begin{array}{c}44 \\
(21.8 \%)\end{array}$ & $\begin{array}{c}41 \\
(20.3 \%)\end{array}$ & $\begin{array}{c}82 \\
(40.6 \%)\end{array}$ & $27(13.4 \%)$ & $\begin{array}{c}8 \\
(4 \%)\end{array}$ & 2.57 & 1.09 \\
\hline Volunteer aid workers** & $\begin{array}{c}12 \\
(46.2 \%)\end{array}$ & $\begin{array}{c}8 \\
(30.8 \%)\end{array}$ & $\begin{array}{c}6 \\
(23.1 \%)\end{array}$ & - & - & 1.76 & .81 \\
\hline
\end{tabular}

(2) Physiological reactions in response to cues of work with clients

\begin{tabular}{|c|c|c|c|c|c|c|c|}
\hline Professional aid workers* & $51(25.2 \%)$ & $75(37.1 \%)$ & $57(28.2 \%)$ & $16(7.9 \%)$ & $\begin{array}{c}3 \\
(1.5 \%)\end{array}$ & 2.23 & .96 \\
\hline Volunteer aid workers** & $15(57.7 \%)$ & $10(38.5 \%)$ & $\begin{array}{c}1 \\
(3.8 \%)\end{array}$ & - & - & 1.46 & .58 \\
\hline
\end{tabular}

(3) Feeling of reliving clients' trauma

\begin{tabular}{|c|c|c|c|c|c|c|c|}
\hline Professional aid workers* & $\begin{array}{c}63 \\
(31.2 \%)\end{array}$ & $\begin{array}{c}47 \\
(23.3 \%)\end{array}$ & $\begin{array}{c}66 \\
(32.7 \%)\end{array}$ & $\begin{array}{c}24 \\
(11.9 \%)\end{array}$ & $\begin{array}{c}2 \\
(1 \%)\end{array}$ & 2.28 & 1.06 \\
\hline Volunteer aid workers** & $14(53.8 \%)$ & $9(34.6 \%)$ & $3(11.5 \%)$ & - & - & 1.57 & .70 \\
\hline
\end{tabular}

\section{(4) Difficulty in sleeping}

\begin{tabular}{|c|c|c|c|c|c|c|c|}
\hline Professional aid workers* & $60(29.7 \%)$ & $58(28.7 \%)$ & $50(24.8 \%)$ & $21(10.4 \%)$ & $13(6.4 \%)$ & 2.35 & 1.19 \\
\hline Volunteer aid workers** & $\begin{array}{c}15 \\
(57.7 \%)\end{array}$ & $\begin{array}{c}8 \\
(30.8 \%)\end{array}$ & $\begin{array}{c}3 \\
(11.5 \%)\end{array}$ & - & - & 1.53 & .70 \\
\hline
\end{tabular}

(5) Sense of a foreshortened future

\begin{tabular}{|c|c|c|c|c|c|c|c|}
\hline Professional aid workers* & $\begin{array}{c}59 \\
(29.2 \%)\end{array}$ & $\begin{array}{c}55 \\
(27.2 \%)\end{array}$ & $\begin{array}{c}47 \\
(23.3 \%)\end{array}$ & $\begin{array}{c}23 \\
(11.4 \%)\end{array}$ & $\begin{array}{c}18 \\
(8.9 \%)\end{array}$ & 2.43 & \\
\hline Volunteer aid workers** & $\begin{array}{c}13 \\
(50 \%)\end{array}$ & $6(23.1 \%)$ & $6(23.1 \%)$ & $\begin{array}{c}1 \\
(3.8 \%)\end{array}$ & - & 1.80 & \\
\hline
\end{tabular}

(6) Psychological distress in response to cues of work with clients

\begin{tabular}{|c|c|c|c|c|c|c|c|}
\hline Professional aid workers* & $37(18.3 \%)$ & $63(31.2 \%)$ & $60(29.7 \%)$ & $34(16.8 \%)$ & $\begin{array}{c}8 \\
(4 \%)\end{array}$ & 2.56 & 1.09 \\
\hline Volunteer aid workers** & $10(38.5 \%)$ & $9(34.6 \%)$ & $5(19.2 \%)$ & $\begin{array}{c}1 \\
(3.8 \%)\end{array}$ & $\begin{array}{c}1 \\
(3.8 \%)\end{array}$ & 2.00 & 1.05 \\
\hline \multicolumn{8}{|l|}{ (7) Detachment from others } \\
\hline Professional aid workers* & $73(36.1 \%)$ & $58(28.7 \%)$ & $53(26.2 \%)$ & $15(7.4 \%)$ & $\begin{array}{c}3 \\
(1.5 \%)\end{array}$ & 2.09 & 1.02 \\
\hline Volunteer aid workers** & $19(73.1 \%)$ & $4(15.4 \%)$ & $3(11.5 \%)$ & - & - & 1.38 & .69 \\
\hline \multicolumn{8}{|c|}{ (8) Exaggerated startle response } \\
\hline Professional aid workers* & $\begin{array}{c}57 \\
(28.2 \%)\end{array}$ & $\begin{array}{c}68 \\
(33.7 \%)\end{array}$ & $\begin{array}{c}46 \\
(22.8 \%)\end{array}$ & $\begin{array}{c}27 \\
(13.4 \%)\end{array}$ & $\begin{array}{c}4 \\
(2 \%)\end{array}$ & 2.27 & 1.07 \\
\hline Volunteer aid workers** & $14(53.8 \%)$ & $8(30.8 \%)$ & $4(15.4 \%)$ & - & - & 1.61 & .75 \\
\hline \multicolumn{8}{|c|}{ (9) Decrease in significant activities } \\
\hline Professional aid workers* & $77(38.1 \%)$ & $56(27.7 \%)$ & $40(19.8 \%)$ & $22(10.9 \%)$ & $\begin{array}{c}7 \\
(3.5 \%)\end{array}$ & 2.13 & 1.14 \\
\hline Volunteer aid workers** & $17(65.4 \%)$ & $6(23.1 \%)$ & $3(11.5 \%)$ & - & - & 1.46 & .70 \\
\hline \multicolumn{8}{|c|}{ (10) Intrusive thoughts about work with clients } \\
\hline Professional aid workers* & $42(20.8 \%)$ & $63(31.2 \%)$ & $71(35.1 \%)$ & $21(10.4 \%)$ & $\begin{array}{c}5 \\
(2.5 \%)\end{array}$ & 2.42 & 1.01 \\
\hline Volunteer aid workers** & $14(53.8 \%)$ & $7(26.9 \%)$ & $4(15.4 \%)$ & - & $\begin{array}{c}1 \\
(3.8 \%)\end{array}$ & 1.73 & 1.00 \\
\hline \multicolumn{8}{|c|}{ (11) Difficulty in concentrating } \\
\hline Professional aid workers* & $\begin{array}{c}76 \\
(37.6 \%)\end{array}$ & $\begin{array}{c}61 \\
(30.2 \%)\end{array}$ & $\begin{array}{c}49 \\
(24.3 \%)\end{array}$ & $\begin{array}{c}11 \\
(5.4 \%)\end{array}$ & $\begin{array}{c}5 \\
(2.5 \%)\end{array}$ & 2.04 & 1.03 \\
\hline Volunteer aid workers** & $\begin{array}{c}11 \\
(42.3 \%) \\
\end{array}$ & $11(42.3 \%)$ & $\begin{array}{c}2 \\
(7.7 \%) \\
\end{array}$ & $\begin{array}{c}2 \\
(7.7 \%) \\
\end{array}$ & - & 1.80 & .89 \\
\hline \multicolumn{8}{|c|}{ (12) Avoidance of people, places, things related to work with clients } \\
\hline Professional aid workers* & $\begin{array}{c}109 \\
(54 \%)\end{array}$ & $\begin{array}{c}42 \\
(20.8 \%) \\
\end{array}$ & $\begin{array}{c}33 \\
(16.3 \%) \\
\end{array}$ & $\begin{array}{c}14 \\
(6.9 \%) \\
\end{array}$ & $\begin{array}{c}4 \\
(2 \%) \\
\end{array}$ & 1.82 & 1.06 \\
\hline
\end{tabular}


Table 2. (continued)

\begin{tabular}{|c|c|c|c|c|c|c|c|}
\hline Volunteer aid workers** & $21(80.8 \%)$ & $4(15.4 \%)$ & $\begin{array}{c}1 \\
(3.8 \%)\end{array}$ & - & - & 1.23 & .51 \\
\hline \multicolumn{8}{|c|}{ (13) Disturbing dreams about work with clients } \\
\hline Professional aid workers* & $130(64.4 \%)$ & $\begin{array}{c}40 \\
(19.8 \%)\end{array}$ & $\begin{array}{c}17 \\
(8.4 \%)\end{array}$ & $\begin{array}{c}10 \\
(5 \%)\end{array}$ & $\begin{array}{c}5 \\
(2.5 \%)\end{array}$ & 1.61 & 1.00 \\
\hline Volunteer aid workers** & $24(92.3 \%)$ & $1(3.8 \%)$ & $1(3.8 \%)$ & - & - & 1.11 & .43 \\
\hline \multicolumn{8}{|c|}{ (14) Avoidance of work with clients } \\
\hline Professional aid workers* & $117(57.9 \%)$ & $37(18.3 \%)$ & $33(16.3 \%)$ & $12(5.9 \%)$ & $\begin{array}{c}3 \\
(1.5 \%)\end{array}$ & 1.74 & 1.02 \\
\hline Volunteer aid workers** & $20(76.9 \%)$ & $4(15.4 \%)$ & $\begin{array}{c}1 \\
(3.8 \%)\end{array}$ & $\begin{array}{c}1 \\
(3.8 \%)\end{array}$ & - & 1.34 & .74 \\
\hline \multicolumn{8}{|l|}{ (15) Irritability } \\
\hline Professional aid workers* & $88(43.6 \%)$ & $54(26.7 \%)$ & $41(20.3 \%)$ & $11(5.4 \%)$ & $\begin{array}{c}8 \\
(4 \%)\end{array}$ & 1.99 & 1.10 \\
\hline Volunteer aid workers** & $10(38.5 \%)$ & $9(34.6 \%)$ & $6(23.1 \%)$ & $\begin{array}{c}1 \\
(3.8 \%) \\
\end{array}$ & - & 1.92 & .89 \\
\hline \multicolumn{8}{|l|}{ (16) Hypervigilance } \\
\hline Professional aid workers* & $90(44.6 \%)$ & $49(24.3 \%)$ & $40(19.8 \%)$ & $13(6.4 \%)$ & $\begin{array}{c}10 \\
(\% 5)\end{array}$ & 2.02 & 1.16 \\
\hline Volunteer aid workers** & $20(76.9 \%)$ & $3(11.5 \%)$ & $\begin{array}{c}1 \\
(3.8 \%)\end{array}$ & $\begin{array}{c}2 \\
(7.7 \%)\end{array}$ & - & 1.42 & .90 \\
\hline \multicolumn{8}{|c|}{ (17) Inability to recall important aspects of work with clients } \\
\hline Professional aid workers* & $\begin{array}{c}93 \\
(46 \%)\end{array}$ & $67(33.2 \%)$ & $30(14.9 \%)$ & $\begin{array}{c}9 \\
(4.5 \%)\end{array}$ & $\begin{array}{c}3 \\
(1.5 \%)\end{array}$ & 1.82 & .94 \\
\hline Volunteer aid workers** & $17(65.4 \%)$ & $6(23.1 \%)$ & $\begin{array}{c}2 \\
(7.7 \%) \\
\end{array}$ & $\begin{array}{c}1 \\
(3.8 \%) \\
\end{array}$ & - & 1.50 & .81 \\
\hline
\end{tabular}

$* N=202, * * N=26$

groups (professional and volunteer relief workers) were compared. Most frequent symptoms reported by professional aid workers were emotional numbing, psychological distress in response to reminders of work with clients, and difficulty in sleeping (58\%, $50.5 \%$, and $41.6 \%$, respectively). Volunteer aid workers most frequently reported foreshortened future, irritability, and psychological distress in response to reminders of work with clients (26.9\%, $26.9 \%$, and $26.8 \%$, respectively). Both study groups experienced psychological distress in response to reminders of work with clients the most. Considering the least experienced symptoms, professional workers reported disturbing dreams, inability to recall information related to clients and irritability (15.9\%, $20.9 \%$, and $29.7 \%$, respectively) while volunteer workers reported physiological reaction in response to cues of work with clients and avoidance of people, places and things related to work with clients (both $3.8 \%$ ). Both study groups experienced having disturbing dreams about work with clients the least. On the other hand, although irritability was among the most experienced symptoms in the volunteer aid workers group; it was one of the least experienced symptoms in the professional aid workers group. Detailed information about the frequency of symptoms of professional and volunteer aid worker groups can be seen in Table 2 .

\section{Results Concerning the Primary Hypothesis of the Study: Type of work}

Mann-Whitney $U$ test was conducted to test the effect of type of work on STS severity. Analyses revealed that STS levels of professional aid workers $(M=$ $36.46, S D=13.42$ ) was significantly greater than those of volunteer aid workers $(M=26.69, S D=$ 7.63), $U=1427.50, z=-3.787, p<.05$ (see Table 3).

Results Concerning the Secondary Hypotheses of the Study: Gender, Age, Education Level, Years of Recruitment, Presence of a Traumatic Incident, and Type of Traumatic Incident

One-way analyses of variance were conducted to examine the effects of gender (female and male), age (18-24, 25-30, 31-40, 41-50, and 51+ years), and education status (high school, higher education, master's degree, and $\mathrm{PhD}$ ) of the aid workers on their STS levels. Ages of the participants were categorized under emerging adulthood, adulthood and 10-year periods after adulthood. Analyses revealed that means of the relevant independent variable levels did not statistically differ from each other. Thus, gender, age, and education status did not have an effect on STS levels of aid workers. 
One-way analysis of variance was conducted to examine the effect of years spent at recruitment (1-5, $6-10,11-15,16-20,21-25$, and 26+ years) on STS levels of the aid workers. Analyses revealed that there was a statistically significant difference between means of the six recruitment year groups, $F(5,225)=2.65, p<.05, \eta^{2}=.057$ (see Table 4). Post hoc comparisons using the Tukey's HSD test indicated that the mean score for 1-5 years of recruitment group $(M=33.37, S D=11.21)$ was significantly lower than the mean score for 11-15 years of recruitment group $(M=40.55, S D=15.29)$. Other groups did not reveal any statistically significant mean differences (see Table 5).

Mann-Whitney $U$ test was conducted to test the effect of presence of a traumatic incident on respondents' STS levels. Analyses revealed that aid workers who reported experiencing a traumatic incident $(M=$ $38.85, S D=14.54$ ) had significantly greater STS levels than those who did not $(M=32.33 S D=$ 11.33), $U=4248.50, z=-3.256, p<.05$ (see Table 6). For further analysis, the reported experienced traumatic incidents of the participants were categorized in terms of having been exposed to the particular incident in their personal life or work life. A oneway analysis of variance was conducted to test the effect of type of traumatic incident on respondents' STS levels. Analyses indicated that the STS levels of the participants whose traumatic incident was induced by a personal life related traumatic event $(M=$ $37.86, S D=15.07)$ did not statistically differ from those of a work life related traumatic event $(M=$ 40.62, $S D=14.61), F(1,86)=0.591, p>.05, \eta^{2}=$ .007 (see Table 7).

\section{DISCUSSION}

Regardless of being primary or secondary, traumatic incidents could have a destructive effect on individuals and people around them. The aim of the current study was to investigate the effect of traumatic incidents faced by aid workers during their service. Analyses conducted to answer the first research question regarding the difference between STS levels of professional and volunteer aid workers revealed that stress levels of professional aid workers were significantly higher than stress levels of volunteers. It might be that traumatic incidents that the professional aid workers are exposed to differ from those of the volunteer aid workers. A majority of the volunteer aid workers were mental health professionals who acted in nongovernmental organizations, which provide psychosocial interventions following disastrous events such as mine incidents, terror bombings, and earthquakes. Most of the workers were exposed to trauma of the client in a relatively safe area such as a closed counseling room or an aid tent. On the other hand, professional group's work involved threating settings such as vehicle crashes, search and rescue following an earthquake, and first aid following a terror bombing. Thus, their exposure to client trauma involves physical threats as well as threat to the self and the client. They are responsible of rescuing the client emergently and immediately. If they fail to provide the service they are responsible for, it might result in catastrophic outcomes. On the other hand, the work of mental health professionals in the volunteer aid worker group requires them to intervene in the aftermath of a disastrous event. However, it is important to point out that the statistically significant difference of STS levels between the professional aid workers and volunteer aid workers might not have been caused by the type of work but by the participants' professions. Another explanation for the difference between the two groups could be that mental health professionals in the volunteer group were trained for intervention for the traumatic events. Thus, they could have had better coping skills, which could have enhanced their management of the negative effects of traumatic incidents. Besides, compared to the professional aid workers, it is more likely that volunteer aid workers have stronger consultation and supervision opportunities which means that they have the potential to protect themselves more actively. Nevertheless, it is important to note that both groups are affected by the services they provide, and it is impossible to say that they are immune to the negative effects of their work.

Regarding the sex variable, findings showed that there was not a significant difference between the STS levels of female and male participants. Reviewing the literature, results supporting and contradicting this finding could be found. Studies done with professionals who investigate sexual abuse cases and professionals who offer support to trauma victims did not reveal statistical differences between the two sex groups (Çolak et al., 2012; Gürdil, 2014). On the contrary, studies conducted with emergency room and outpatient clinic health workers revealed that the traumatic levels of female workers were statistically higher than those of male workers (Haksal, 2007; Yeşil, 2010). Regarding the finding of the current study, not observing a statistically significant difference between STS levels of female and male participants could be explained by the fact that both participant groups serve under the same work conditions. Looking from a sociological perspective, it could be possible to suggest that workplaces of the participants offer a gender equal job responsibility.

The current study showed that participants who have been working for 11-15 years presented higher STS levels compared to those who have been working for 1-5 years. It might be that experienced workers experience an accumulated level of stress. They 
could have faced stress over and over during their long recruitment years and this overwhelming pressure could have led them to struggle with some kind of an exhaustion and weariness; which is termed burnout. Studies conducted on secondary traumatization and burnout reveal a correlation between the two experiences (Adams, et.al, 2006; Gürdil Birinci \& Erden, 2016; Salston \& Figley, 2003). Thinking that the participants of this study who have been working for 11-15 years could be aged between early-30s to mid-30s, it can be said that they are going through a phase of questioning their life and desired goals in terms of whether or not they have reached them. Considering their age, it might also be that they are trying to change the conditions and situations that they are not happy with such as a low-paying job, an unhappy marriage, etc. (Berk, 2010). Any discrepancy between the desired and reached goals in a person's life will result in dissatisfaction, which might make the person more fragile to stressful events (Palabıyıkoğlu, 2000). Regarding the recruitment duration variable, there are both supporting and contradictory findings within the literature. Studies investigating the relationship between years spent at recruitment and vicarious trauma levels have shown that there is a negative and statistically significant difference between the study groups (Altekin, 2014; Schwartz, 2008). On the other hand, there are also some examples that do not reveal any statistical differences in this comparison (Gürdil, 2014).

The findings of the present study did not reveal any statistically significant difference between education levels of the participants. While one study carried out with social workers supported this finding (Schwartz, 2008), studies conducted with professionals working with alcoholic patients did not support this result (Ewer et al., 2014; Y1lmaz, 2006).

The current study also investigated if presence of a traumatic incident had an effect on STS levels of the participants. Analyses revealed that participants who did not report any perceived personal traumatic incident showed lower STS levels compared those who have reported any perceived personal traumatic incidents. That is, participants who have experienced a traumatic event reported higher STS levels than non-experiencers. This finding could point to the possibility that participants who experienced a personal traumatic event could not manage to develop efficient coping strategies (Littleton et al., 2007). Their personal traumatic incidents might have been augmented by exposure to client trauma and this might have increased their vulnerability to STS (Collins \& Long, 2003). Consistently, studies conducted with professionals working with trauma victims and emergency room health workers revealed a statistically significant and positive relationship betwee presence of a personal traumatic event and STS levels (Gürdil, 2014; Yeşil, 2010).

An important finding of the current study concerned the relationship between type of personal traumatic incident and STS levels of the participants. As mentioned earlier, participants' report of personal traumatic events was categorized as either being work life related or personal life related incident. The analyses showed that there was not a statistically significant difference between incident categories in terms of STS levels. This finding is striking as it suggests that a work life related traumatic incident has similar impact on the person as the personal life related traumatic incident. Participants' type of incident exposure did not have any importance; the outcomes of trauma were the same whether it was a work life related incident or a personal life related incident.

The current study has several limitations. The characteristics of the sample is an issue that should be considered. Most of them were employees in healthrelated industry; thus, they might have had a general idea of what was being investigated in the measurement instrument and given biased answers for social desirability. Another limitation of the study concerned directly asking participants about their traumatic event experiences ("Did you experience a life event which you consider to be a traumatic incident?"). Using a traumatic events checklist might have revealed incidents which in fact are traumatic but failed to be recognized so by the participants. A further limitation of the study was that the number of participants in the volunteer aid worker group was relatively low compared to professional aid worker group. Effort given to increase participation of volunteer aid workers, unfortunately, remained unanswered. Response rate of the organizations and associations from which volunteer aid workers participated was low. In addition to that, volunteers who work in cases of disasters and emergencies are rooted. For instance, in the case of an earthquake volunteers who reach the affected area are pretty much the same people who serve as relief workers in the case of a terror bombing. For this reason, the number of participants in the aid workers group was limited. Replicating the present study with a larger sample might yield different findings. Moreover, it is thought that, replicating the study with larger samples would allow for comparison of the secondary traumatization of volunteer and professional aid workers.

\section{Conclusion}

Providing any kind of helping behavior for trauma victims as a profession carries the risk for secondary traumatization. The findings of the current study identified the following risk factors: type of work, years spent at recruitment, and presence of a 
perceived traumatic event. In this context, it is crucial to minimize the negative effects of trauma work on aid workers and establish efficient protective factors. Together with taking personal precautions regarding the issue, employers and/or organizations that provide such services should take some actions to protect their workers' psychological well-being. Arranging fair working hours, holding group-sharing sessions, offering supervision support, investigating the traumatic stress of the employees periodically, holding psycho-education sessions on trauma and its outcomes are some of the actions that could be taken by the employers and/or organizations (Kahil \& Palabıyıkoğlu, 2018).

\section{REFERENCES}

Adams, R. E., Boscarino, J. A., \& Figley, C. R. (2006). Compassion fatigue and psychological distress among social workers: A validation study. American Journal of Orthopsychiatry, 76(1), 103-108.

Altekin, S. (2014). Vicarious traumatization: An investigation of the effects of trauma work on mental health professionals in turkey. (Unpublished doctoral thesis). Boğaziçi University/School of Social Sciences, İstanbul.

American Psychiatric Association (2000). Diagnostic and Statistical Manual of Mental Disorders-Text Revised ( $4^{\text {th }}$ ed., TR). Washington, DC: Author.

Beaton, R. D., Murphy, S., Johnson, L. C., \& Nemuth, M. (2004). Secondary traumatic stress response in fire fighters in the aftermath of 9/11/2001. Traumatology, 10(1), 7-16.

Beck, C. T. (2011). Secondary traumatic stress in nurses: A systematic review. Archives of Psychiatric Nursing, 25(1), 1-10.

Berk, L. E. (2010). Development through the lifespan (463-497). Boston, MA: Pearson.

Bonach, K., \& Heckert, A. (2012). Predictors of secondary traumatic stress among children's advocacy center forensic interviewers. Journal of Child Sexual Abuse, 21(3), 295-314.

Bride, B. E. (2007). Prevalence of secondary traumatic stress among social workers. Social Work, 52(1), 6370.

Bride, B. E., Jones, J. L., \& Macmaster, S. A. (2008). Correlates of secondary traumatic stress in child protective services workers. Journal of Evidence-Based Social Work, 4(3-4), 69-80.

Bride, B. E., Robinson, M. M., Yegidis, B., \& Figley, C. R. (2004). Development and validation of the secondary traumatic stress scale. Research on Social Work Practice, 14, 27-35.

Bride, B., Smith Hatcher, S., \& Humble, M. N. (2009). Trauma training, trauma practices, and secondary traumatic stress among substance abuse counselors. Traumatology, 15(2), 96-105.

Choi, G. Y. (2011). Secondary traumatic stress of service providers who practice with survivors of family or sexual violence: A national survey of social workers.
Smith College Studies in Social Work, 81(1), 101119.

Çolak, B., Şişmanlar, Ş. G., Karakaya, I., Etiler, N., \& Biçer, Ü. (2012). Çocuk cinsel istismarı olgularını değerlendiren meslek gruplarında dolaylı travmatizasyon [Vicarious traumatization in professionals working with sexually abused children]. Anatolian Journal of Psychiatry, 13, 51-58.

Collins, S., \& Long, A. (2003). Working with the psychological effects of trauma: consequences for mental health-care workers-a literature review. Journal of Psychiatric and Mental Health Nursing, 10(4), 417424.

Creamer, T. L., \& Liddle, B. J. (2005). Secondary traumatic stress among disaster mental health workers responding to the September 11 attacks. Journal of Traumatic Stress: Official Publication of the International Society for Traumatic Stress Studies, 18(1), 8996.

Devilly, G. J., Wright, R., \& Varker, T. (2009). Vicarious trauma, secondary traumatic stress or simply burnout? Effect of trauma therapy on mental health professionals. Australian and New Zealand Journal of Psychiatry, 43(4), 373-385.

Dirkzwager, A. J. E., Bramsen, I., Adér, H., \& van der Ploeg, H. M. (2005). Secondary traumatization in partners and parents of dutch peacekeeping soldiers. Journal of Family Psychology, 19(2), 217-226.

Dominguez-Gomez, E., \& Rutledge, D. N. (2009). Prevalence of secondary traumatic stress among emergency nurses. Journal of Emergency Nursing, 35(3), 199204.

Duffy, E., Avalos, G., \& Dowling, M. (2015). Secondary traumatic stress among emergency nurses: a crosssectional study. International emergency nursing, 23(2), 53-58.

Ewer, P. L., Teesson, M., Sannibale, C., Roche, A., \& Mills, K. L. (2014). The prevalence and correlates of secondary traumatic stress among alcohol and other drug workers in australia. Drug and Alcohol Review, 34(3), 252-258.

Figley, C. R. \& Kleber, R. J. (1995). Beyond the "victim" secondary traumatic stress. In Rolf J. Kleber, Charles R. Figley, Berthold P. R. Gersons (Eds.), Beyond Trauma: Cultural and Societal Dynamics (pp. 75-89). New York, Springer.

Figley, C. R. (1995). Compassion fatigue as secondary traumatic stress disorder: An overview. In Charles R. Figley (Ed.), Compassion fatigue coping with secondary traumatic stress disorder in those who treat traumatized (pp. 1-20). New York, NY: Routledge.

Figley, C. R. (1998). Introduction. In Charles R. Figley (Ed.), Burnout in Families: The Systematic Costs of Caring (s. 7). New York: CRC.

Gürdil Birinci, G., \& Erden, G. (2016). Yardım çalışanlarında üstlenilmiș travma, ikincil travmatik stres ve tükenmişliğin değerlendirilmesi [Evaluation of vicarious trauma, secondary traumatic stress and burnout in aid workers]. Turkish Journal of Psychology, 31(77), 10-26.

Gürdil, G. (2014). Üstlenilmiş travma ve ikincil travmatik stresin travmatik yaşantılara müdahale eden bir grup üzerinde gestalt temas biçimleri çerçevesinde 
değerlendirilmesi [The assessment of vicarious trauma and secondary traumatic stress of a group of trauma workers within the frame of Gestalt contact styles]. (Unpublished doctoral dissertation). Ankara University/Institute of Social Sciences, Ankara.

Haksal, P. (2007). Acil servis personelinde görülen ikincil travmatik stres düzeyinin disosiyasyon düzeyi, sosyal destek algısı ve başa çıkma stratejileri açısından incelenmesi [The investigation of secondary traumatic stress levels observed in emergency service personnel in terms of dissociation level, perceived social support and coping strategies]. (Unpublished doctoral dissertation). Hacettepe University/Institute of Social Sciences, Ankara.

Healy, S., \& Tyrrell, M. (2011). Stress in emergency departments: experiences of nurses and doctors. Emergency nurse, 19(4).

Kahil, A., \& Palabıyıkoğlu, N. R. (2018). İkincil travmatik stres [Secondary traumatic stress]. Current Approaches in Psychiatry, 10(1), 59-70.

Kaya, A. (2005). Çocuklar için yalnızlık ölçeğinin türkçe formunun geçerlik ve güvenirlik çalışması. Journal of Research in Education, 19, 220-237.

Littleton, H., Horsley, S., John, S., \& Nelson, D. V. (2007). Trauma coping strategies and psychological distress: A meta-analysis. Journal of Traumatic Stress: Official Publication of the International Society for Traumatic Stress Studies, 20(6), 977-988.

Ortlepp, K., \& Friedman, M. (2002). Prevalence and correlates of secondary traumatic stress in workplace lay trauma counselors. Journal of Traumatic Stress, 15(3), 213-222.

Palabıyıkoğlu, R. (2000). Gelişimsel yaşam krizleri [Developmental life crises]. Kriz ve Krize Müdahale [Crisis and Crisis Intervention]. Ankara: A.U. Psychiatric Crisis Application and Research Center, 6(67).

Perez, L., Jones, J., Englert, D. R., \& Sachau, D. (2010). Secondary traumatic stress and burnout among law enforcement investigators exposed to disturbing media images. Journal of Police and Criminal Psychology, 23, 113-124.

Robins, P. M., Meltzer, L., \& Zelikovsky, N. (2009). The experience of secondary traumatic stress upon care providers working within a children's hospital. Journal of Pediatric Nursing, 24(4), 270-279.

Saakvitne, K. W. (2002). Shared trauma: The therapist's increased vulnerability. Psychoanalytic Dialogues, 12(3), 443-449.

Salston, M., \& Figley, C. R. (2003), Secondary traumatic stress effects of working with survivors of criminal victimization. Journal of Traumatic Stress, 16, 167174.

Schwartz, R. (2008). Working conditions and secondary traumatic stress. (Unpublished doctoral dissertation). Yeshiva University/Wurzweiler School of Social Work, New York.

Smith Hatcher, S., Bride, B. E., Oh, H., King, D. M., \& Catrett, J. J. F. (2011). An assessment of secondary traumatic stress in juvenile justice education workers. Journal of Correctional Health Care, 17(3), 208-217.

Ting, L., Jacobson, J. M., Sanders, S., Bride, B. E., \& Harrington, D. (2005). The secondary traumatic stress scale: Confirmatory factor analyses with a national sample of mental health social workers. Journal of Human Behavior in the Social Environment, 11(3-4), 177-194.

Wagner, D., Heinrichs, M., \& Ehlert, U. (1998). Prevalence of symptoms of posttraumatic stress disorder in German professional firefighters. American Journal of Psychiatry, 155(12), 1727-1732.

Yeșil, A. (2010). 112 acil să̆lık hizmetlerinde çalışan sağlık çalışanlarında ruhsal travma ve ilişkili sorunların yaygınlığ [Psychological trauma and related problems of prevelance among 112 healthcare providers]. (Unpublished master's dissertation). Kocaeli University/Institute of Health Sciences, Kocaeli.

Yıldırım, G., Kıdak, L. B., \& Yurdabakan, I. (2018). Secondary Traumatic Stress Scale: An adaptation study. Anadolu Psikiyatri Dergisi, 19(1), 45-52.

Yılmaz, B. \& Şahin, N. H. (2007). Arama kurtarma çalışanlarında travma sonrası stres belirtileri ve travma sonrası büyüme [Posttraumatic Stress Symptoms and Posttraumatic Growth in Rescue Workers]. Turkish Journal of Psychology, 22(59), 119-133.

Yılmaz, B. (2006). Arama kurtarma çalışanlarında travma sonrasi stres belirtileri ve travma sonrası büyüme ile ilişkili değişkenler [Posttraumatic stress symptoms and posttraumatic growth in rescue workers]. (Doctoral dissertation). Ankara University/Institute of Social Sciences, Ankara. 